The Journal of Animal \& Plant Sciences, 30(3): 2020, Page: 552-559

ISSN (print): 1018-7081; ISSN (online): 2309-8694

\title{
PREDICTION OF LIVE BODY WEIGHT USING BODY MEASUREMENTS FOR JAWA BREBES (JABRES) CATTLE
}

\author{
M. S. Haq ${ }^{1},{ }^{*}$ I. G. S. Budisatria ${ }^{1}$, P. Panjono ${ }^{1}$ and D. Maharani ${ }^{1}$ \\ Faculty of Animal Science, Universitas Gadjah Mada, Jl. Fauna No 3, Bulaksumur, Yogyakarta, 55281, Yogyakarta, \\ Indonesia \\ ${ }^{1}$ Corresponding author’s email: budisatria@ugm.ac.id
}

\begin{abstract}
Bodyweight estimation is important for any aspect of livestock management. Jabres cattle farmers use bodyweight estimation to determine the cattle price in the traditional market. Nowadays, they only use eye-based assessment to predict cattle body weight with a lot of inaccuracies. In this study, the cattle body weight was estimated based on body size measurements data, namely body length, heart girth, withers height, rump height, face length, and face width. The data were collected from Jabres cattle reared in the district of Bantarkawung, Brebes, Central Java, Indonesia. The data were taken from 521 Jabres cattle which were stratified by sex and age. Generally, male Jabres cattle have a smaller body size than female Jabres cattle and younger cattle have significant smaller body size than elder cattle. The highest correlation coefficient came from body weight and heart girth. The equation to predict body weight was obtained by multiple linear regression and factorial analysis scores followed by multiple linear regression methods. The result showed that multiple linear regression method was preferable to be used to predict body weight of Jabres cattle because of its better accuracy, better fitness, and more applicable for Jabres cattle farmers.
\end{abstract}

Key words: Body weight prediction, Jabres cattle, native cattle, Indonesia

https://doi.org/10.36899/JAPS.2020.3.0065

Published online March 25, 2020

\section{INTRODUCTION}

Jabres cattle are one of the Indonesian native cattle, which is very potential to be used in meat production. Like its name, Jabres (Jawa-Brebes) cattle came from Brebes Regency and has been stated by the Ministry of Agriculture as one of the native cattle that should be protected and conserved. The conservation of Jabres cattle was written in The Decree of Ministry of Agriculture No. 2842/Kpts/LB.430/8/2012 on August $13^{\text {th }}, 2012$. This decree also stated that Jabres cattle come from the crossbreeding of Ongole cattle, Madura cattle, and Bali cattle. Jabres cattle have been cultured hereditary by the community in some places in Brebes Regency (Adiwinarti et al. 2010; Lestari et al. 2014). Jabres cattle have uniform physical shape and good adaptation ability in a various environment of Brebes Regency which composed of lowland and highland (Ministry of Agriculture of Indonesian Republic 2012). Jabres cattle are maintained by being released in natural pastures in the morning until late in the evening and at night in the stall. The feed given is only grass that is in natural pasture. Jabres cattle have similar characteristics with Pasundan (Said et al. 2017), Aceh (Putra et al. 2014a), and Madura cattle (Sutarno and Setyawan 2016).

Body size is one of the phenotype characteristics (Abdullah et al. 2007; Adinata et al. 2016; Said et al. 2017). The cattle body size is composed of withers height, hip height, body length, heart girth, head index, and body weight. Body size properties are used to characterize the different breeds of livestock as they give an idea of body conformation (Pundir et al., 2011) and identify diversity within and between district breeds, based on their observable attributes (FAO 2011). The Jabres cattle body size measurement data can be used to make standardization of Jabres cattle body size which had not been performed yet. It brought the development of Jabres cattle aimless and cross-breeding happened in many places. If the cross-breeding was not prevented by making the standard, the germ plasm of Jabres cattle would be lost in several years later. Therefore, the identification of Jabres cattle body size is very important in order to conserve its germ plasm.

The studies of live body weight prediction in cattle have been performed previously. The prediction of live body weight in female Bali cattle and Aceh cattle had been performed using hearth girth by correlation and regression analysis (Ni'am et al. 2012; Putra et al. 2014b). The body weight prediction in Ongole cattle had been performed based on body length and heart girth by using simple regression analysis (Paputungan et al. 2013). Suliani et al. (2017) used body length and chest circumference to predict body weight in male Simmental Ongole Crossbred by simple regression analysis (Suliani et al. 2017). In addition, body weight, carcass weight, and live weight of male Simmental Ongole Crossbreed bulls had been performed by multiple linear regression using body length, abdominal girth, hump height, coxae width, root tail width, neck width, and hearth depth (Prabowo et al. 2012). 
Body weight is one parameter that used as a reference for the farmer to evaluate their husbandry fruitfulness. However, weighing is not always feasible and therefore live weight is often estimated from easily accessible body size data (Mutua et al. 2011). Live body weight prediction is an important factor associated with several management practice, including selection for slaughter or breeding, determining feeding levels, administration of veterinary product. Furthermore, body weight is also a good indicator of animal condition (Ulutas et al. 2002). For Jabres cattle farmer, the live body weight is very important factor in determining the cattle sell price in the market. They cannot weight the cattle by digital weighing scale because most of the Jabres cattle farmers live in rural region. Nowadays, they estimated the cattle live body weight only by eye-based assessment or they called "Jogrog" method, without weighing or measuring the cattle body size. More accurate method for live body weight estimation was needed in order to help farmers reach the proper cattle price. The main purpose of this study was to predict live body weight of Jabres cattle based on their body size measurements result, especially in district of Bantarkawung, Brebes, Central Java, Indonesia. The validation of the body weight estimation equation was also provided.

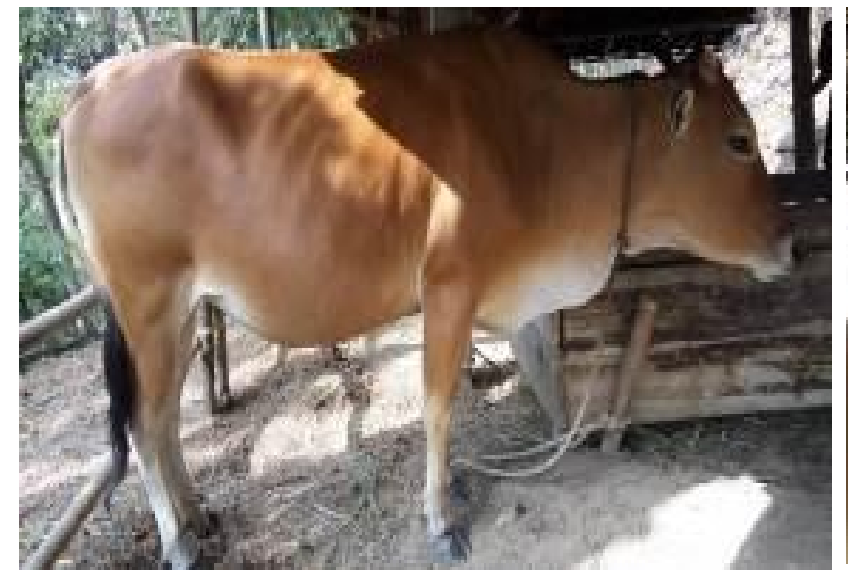

Fig. 1. Female (left) and male (right) Jabres cattle.

The descriptive analysis was performed by calculating the mean, standard deviation (SD), and coefficient of variance $(\mathrm{CV} \%)$. The data were stratified by sex and age (under 1 years old and same or above 1 years old). Multivariate Anova was performed in order to explore the significance of difference for measurement result between groups. The Pearson's correlation coefficients among various body measurements were also calculated.

In order to gain accurate live body weight prediction equation based on body size measurements, the regression analysis was performed by multiple linear

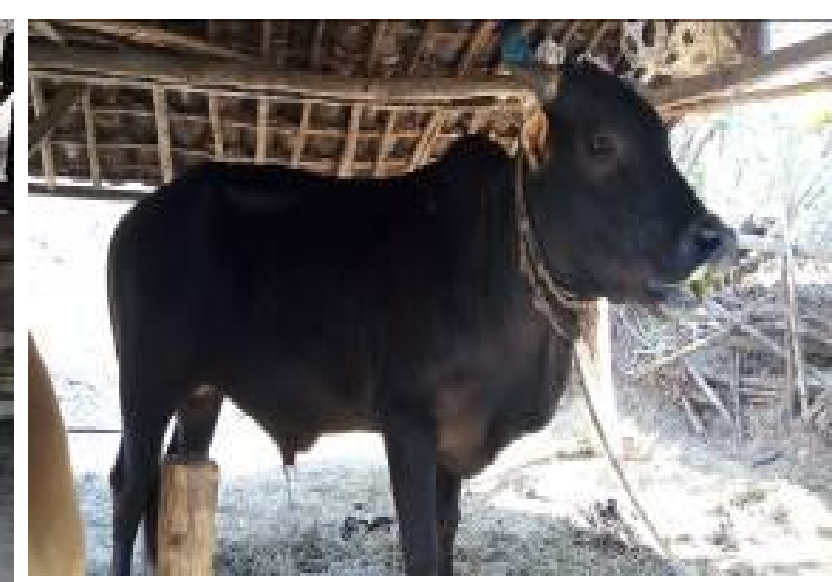

\section{MATERIALS AND METHODS}

This research was conducted in Bantarkawung District (Brebes Regency, Central Java) from January 7th to May 20th, 2017. The number of cattle measured in this study was 521 heads which detailed below:

\section{Table 1. Number of Sample Size.}

\begin{tabular}{lccc}
\hline $\begin{array}{l}\text { Number of Sample } \\
\text { Size }\end{array}$ & $\begin{array}{c}<\text { 1 years } \\
\text { old }\end{array}$ & $\begin{array}{c}\geq \mathbf{1} \text { years } \\
\text { old }\end{array}$ & Total \\
\hline Female & 79 & 322 & 401 \\
Male & 44 & 76 & 120 \\
Total & 123 & 398 & 521 \\
\hline
\end{tabular}

Jabres cattle pictures can be seen in Fig. 1. The cattle body size was measured using stationery, weight scale, measuring tape and ruler. when animals were standing as described in Ozkaya and Bozkurt (2008). The measurement parameter are Body Length (BL), Heart Girth (HG), Withers Height (WH), Rump Height (RH), Face Length (FL), Face Width (FW), and Body Weight (BW) Tolenkhomba et al. (2012). The gained data was analyzed statistically by IBM SPSS 19 Software. Normality test was performed for the collected data using Kolmogoro-Smirnov and Q-Q Plot methods.

regression and factorial analysis scores followed by multiple linear regression methods. In the multiple linear regression methods, the cattle body weight was predicted by using measured body size parameter as independent variables using the following multiple regression model: $Y=\alpha+\beta_{1} \cdot X_{1}+\beta_{2} \cdot X_{2}+\beta_{3} \cdot X_{3}+\ldots+\beta_{n} \cdot X_{n}+E_{n}$

Where $\mathrm{Y} \quad$ : Body weight (in kg unit)

$\alpha \quad$ : Regression constant

$\beta_{1}, \beta_{2}, \ldots, \beta_{\mathrm{n}} \quad$ : Regression coefficient for $\mathrm{n}^{\text {th }}$ body

size parameter

$\mathrm{X}_{1}, \mathrm{X}_{2}, \ldots, \mathrm{X}_{\mathrm{n}} \quad$ : The observed variables

$\mathrm{E} \quad$ : Residual error 
In the factorial analysis, the factor was extracted by principle components with factor number based on Eigenvalue greater than 1. The Kaiser-Meyer-Olkin Measure of Sampling Adequacy coefficient, Barlett's Test of Sphericity significance, and anti-image correlation was evaluated in order to make sure the data appropriateness for factorial analysis. In this method, the variables may be expressed as linear functions of the factors with equation below,

$\mathrm{X}_{1}=\mathrm{a}_{11} \mathrm{~F}_{1}+\mathrm{a}_{12} \mathrm{~F}_{2}+\ldots+\mathrm{a}_{1 \mathrm{~m}} \mathrm{~F}_{\mathrm{m}}+\mathrm{a}_{1} \mathrm{U}_{1}$

$X_{2}=a_{21} F_{2}+a_{22} F_{2}+\ldots+a_{2 m} F_{m}+a_{2} U_{2}$

$X_{n}=a_{n 1} F_{1}+a_{n 2} F_{2}+\ldots+a_{n m} F_{m}+a_{n} U_{n}$

Where $\mathrm{X}_{1}, \mathrm{X}_{2}, \ldots, \mathrm{X}_{\mathrm{n}} \quad$ : The observed variables

$a_{11}, a_{12}, \ldots, a_{n m}$ : Coefficients which best

reproduce the observed variable $\mathrm{n}$ from the factors $\mathrm{m}$

$\mathrm{F}_{1}, \mathrm{~F}_{2}, \ldots, \mathrm{F}_{\mathrm{m}} \quad:$ The extracted factors

$\mathrm{U}_{1}, \mathrm{U}_{2}, \ldots, \mathrm{U}_{\mathrm{n}} \quad$ : The unique factors

The cattle body weight was predicted by using factor scores as independent variables using the following multiple regression model:

$\mathrm{Y}=\mathrm{a}+\mathrm{b}_{1} \mathrm{FS}_{1}+\mathrm{b}_{2} \mathrm{FS}_{2}+\ldots+\mathrm{b}_{\mathrm{k}} \mathrm{FS}_{\mathrm{k}}+\mathrm{e}$

Where: $\mathrm{Y} \quad=$ Cattle body weight (in kg unit)

a $\quad=$ Regression constant

$b_{\mathrm{k}} \quad=$ Regression coefficient for factor score of $\mathrm{k}$

FS $\quad=$ Factor score

e $\quad=$ Random error term

Normality test of the residual from each equation was evaluated by Kolmogoro-Smirnov and Q-Q Plot methods. The fitness of the body weight prediction equations from both methods were evaluated by calculating the adjusted $\mathrm{R}^{2}$, RMSE, and standard deviation ratio values. The best equations were chosen based on the highest adjusted $\mathrm{R}^{2}$ value and the lowest RMSE and standard deviation ratio values.

\section{RESULTS AND DISCUSSION}

The Identification of Jabres Cattle Body Size Properties: The descriptive statistics for body measurement and body weight of Jabres cattle was presented in Table 2 . The data were stratified by sex and age $(<1$ years old and $\geq 1$ years old $)$ because the multivariate test result showed that there are significant differences among these data sets $(\mathrm{P}<0.05)$. The data obey normal distribution which indicated by KolmogoroSminov significance value greater than 0.50 or the Q-Q plot results where the data located around the normal line. From these data, it can be seen that age really matters to most of the body size parameter of Jabres cattle because the younger cattle have significant smaller body size than elder cattle. Generally, male Jabres cattle under 1 years old have significant smaller body size than female Jabres cattle under 1 years old, except for face length and face width which are not significantly different. However, for cattle same or above 1 years old, there are no significant difference between male and female cattle although female cattle have bigger body length, heart girth, face length, and body weight than male cattle. This result was a little bit different with previous research due to the different sample size (Adinata et al. 2016; Panjono et al. 2017).

Compared to Aceh cattle, adult female Jabres cattle had bigger body size than adult female Aceh cattle but adult male Jabres cattle had smaller body size than adult male aceh cattle (Putra et al. 2014a). Compared to adult female Ongole grade cattle, adult female Jabres cattle had smaller body size (Paputungan et al. 2013)

Table 2. Mean, standard deviation (SD) and coefficient of variation (CV in \%) for body size and body weight of Jabres cattle.

\begin{tabular}{|c|c|c|c|c|c|c|c|c|c|c|c|c|}
\hline \multirow{3}{*}{ Varia-ble } & \multicolumn{6}{|c|}{ Female } & \multicolumn{6}{|c|}{ Male } \\
\hline & \multicolumn{3}{|c|}{$<1$ years old } & \multicolumn{3}{|c|}{$\geq 1$ years old } & \multicolumn{3}{|c|}{$<1$ years old } & \multicolumn{3}{|c|}{$\geq 1$ years old } \\
\hline & Mean & \pm SD & CV (\%) & Mean & $\pm \mathrm{SD}$ & CV (\%) & Mean & $\pm \quad \mathrm{SD}$ & CV (\%) & Mean & $\pm \mathrm{SD}$ & CV (\%) \\
\hline $\mathrm{n}$ & & 79 & & & 322 & & & 44 & & & 76 & \\
\hline $\mathrm{BL}$ & 80,75 & $\pm 13,58^{\mathrm{b}}$ & 16,82 & 101,52 & $\pm 8,36^{\mathrm{c}}$ & 8,23 & 75,25 & $\pm 12,60^{\mathrm{a}}$ & 16,74 & 99,81 & $\pm 11,99^{\mathrm{c}}$ & 12,01 \\
\hline HG & 119,60 & $\pm 20,11^{\mathrm{b}}$ & 16,81 & 147,41 & $\pm 9,62^{\mathrm{c}}$ & 6,52 & 112,52 & $\pm 17,28^{\mathrm{a}}$ & 15,36 & 144,84 & $\pm 15,71^{\mathrm{c}}$ & 10,85 \\
\hline WH & 99,91 & $\pm 11,41^{\mathrm{b}}$ & 11,42 & 113,07 & $\pm 6,73^{\mathrm{c}}$ & 5,95 & 95,36 & $\pm 12,24^{\mathrm{a}}$ & 12,84 & 113,09 & $\pm 7,45^{\mathrm{c}}$ & 6,59 \\
\hline RH & 103,85 & $\pm 11,53^{b}$ & 11,10 & 116,94 & $\pm 6,85^{\mathrm{c}}$ & 5,86 & 100,32 & $\pm 11,66^{\mathrm{a}}$ & 11,62 & 117,36 & $\pm 6,93^{c}$ & 5,91 \\
\hline FI & 33,76 & $\pm 5,97^{\mathrm{a}}$ & 17,70 & 40,19 & $\pm 2,78^{\mathrm{b}}$ & 6,93 & 32,53 & $\pm 6,37^{\mathrm{a}}$ & 19,59 & 39,89 & $\pm 4,59^{\mathrm{b}}$ & 11,52 \\
\hline FW & 15,20 & $\pm 3,16^{\mathrm{a}}$ & 20,77 & 17,22 & $\pm 1,95^{\mathrm{b}}$ & 11,35 & 14,86 & $\pm 2,91^{\mathrm{a}}$ & 19,55 & 17,83 & $\pm 3,02^{\mathrm{b}}$ & 16,95 \\
\hline BW & 113,71 & $\pm 47,24^{\mathrm{b}}$ & 41,54 & 205,72 & $\pm 35,52^{\mathrm{c}}$ & 17,27 & 93,77 & $\pm 38,89^{\mathrm{a}}$ & 41,47 & 199,74 & $\pm 62,37^{c}$ & 31,23 \\
\hline
\end{tabular}

Note : ${ }^{\text {a,b,c }}:$ different superscript indicates the significant differen $(\mathrm{P}<0.05)$

$\mathrm{n}$ : sample size, BL: Body length, HG: Heart girth, WH: Withers height, RH: Rump height, FL: Face length, FW: Face width, BW: Body weight.

Correlation Analysis of Body Size of Jabres Cattle: The correlation analysis of body size of Jabres Cattle is performed separately for each cattle group. The correlation analysis result for Jabres cattle body size was shown in Table 3. Morphology or body size expresses a strong relationship with productive potential since it 
contains the structure which supports the biological functionality of the animal.

Jabres cattle have strong correlation among body size parameter in every group except female Jabres cattle same or above 1 years old. It can be happen because the cattle growth after 2 years old did not obey the linear curve (Gano et al. 2015). The same condition also happen for Bali cattle (Ni'am et al. 2012). In this study, there were large number of female Jabres cattle with age above 2 years old meanwhile there were only a little male Jabres cattle with age above 2 years old. In Brebes, male cattle with age nore than 2 years old could be found rarely because community used 2-years old male cattle to be slaughtered in religio(Ni'am et al. 2012; Putra et al. 2014a; Thiruvenkadan 2015)us events every year. So that, the population of female Jabres cattle was bigger than male Jabres cattle.
Related to body weight, all cattle have very strong correlation with heart girth as the highest corelation coefficient. It followed by body length and withers height for female cattle in all ages and male cattle same or above 1 years old. Meanwhile, for male cattle under 1 years old, the heart girth was followed by rip height and withers height. This result was consistent with Ni'am et al. (2012); Putra et al. (2014b); Thiruvenkadan (2015) who stated that cattle body weight had the strongest correlation with hearth girth compared to another body size parameter (Ni'am et al. 2012; Thiruvenkadan 2015). Compared to another animal, heart girth also became an important parameter to predict body weight of the pig (Mutua et al. 2011) and goat (Adeyinka and Mohammed 2006).

Table 3. Correlation coefficient for body size of Jabres cattle.

\begin{tabular}{|c|c|c|c|c|c|c|c|}
\hline & BL & HG & WH & RH & FL & FW & BW \\
\hline \multicolumn{8}{|c|}{ Female $<1$ years old } \\
\hline BL & 1,000 & & & & & & \\
\hline HG & $0,716^{* *}$ & 1,000 & & & & & \\
\hline WH & $0,707^{* *}$ & $0,867^{* *}$ & 1,000 & & & & \\
\hline $\mathrm{RH}$ & $0,698^{* *}$ & $0,853^{* *}$ & $0,956^{* *}$ & 1,000 & & & \\
\hline FL & $0,718^{* *}$ & $0,831^{* *}$ & $0,783^{* *}$ & $0,777^{* *}$ & 1,000 & & \\
\hline FW & $0,508^{* *}$ & $0,734^{* *}$ & $0,620^{* *}$ & $0,608^{* *}$ & $0,729^{* *}$ & 1,000 & \\
\hline BW & $0,864^{* *}$ & $0,946^{* *}$ & $0,836^{* *}$ & $0,817^{* *}$ & $0,823^{* *}$ & $0,688^{* *}$ & 1,000 \\
\hline \multicolumn{8}{|c|}{ Female $\geq 1$ years old } \\
\hline $\mathrm{BL}$ & 1,000 & & & & & & \\
\hline HG & $0,250^{* *}$ & 1,000 & & & & & \\
\hline WH & $0,140^{*}$ & $0,591^{* *}$ & 1,000 & & & & \\
\hline RH & $0,135^{*}$ & $0,559^{* *}$ & $0,848^{* *}$ & 1,000 & & & \\
\hline FL & 0,026 & $0,452^{* *}$ & $0,182^{* *}$ & $0,197^{* *}$ & 1,000 & & \\
\hline FW & $-0,069$ & $0,241^{* *}$ & $-0,008$ & $0,142^{*}$ & $0,397^{* *}$ & 1,000 & \\
\hline BW & $0,675^{* *}$ & $0,854^{* *}$ & $0,507^{* *}$ & $0,485^{* *}$ & $0,338^{* *}$ & $0,149^{* *}$ & 1,000 \\
\hline \multicolumn{8}{|c|}{ Male $<1$ years old } \\
\hline $\mathrm{BL}$ & 1,000 & & & & & & \\
\hline HG & $0,713^{* *}$ & 1,000 & & & & & \\
\hline WH & $0,654^{* *}$ & $0,898^{* *}$ & 1,000 & & & & \\
\hline RH & $0,725^{* *}$ & $0,921^{* *}$ & $0,964^{* *}$ & 1,000 & & & \\
\hline FL & $0,662^{* *}$ & $0,760^{* *}$ & $0,677^{* *}$ & $0,663^{* *}$ & 1,000 & & \\
\hline FW & $0,421^{* *}$ & $0,778^{* *}$ & $0,652^{* *}$ & $0,670^{* *}$ & $0,584^{* *}$ & 1,000 & \\
\hline BW & $0,820^{* *}$ & $0,965^{* *}$ & $0,851^{* *}$ & $0,887^{* *}$ & $0,755^{* *}$ & $0,689^{* *}$ & 1,000 \\
\hline \multicolumn{8}{|c|}{ Male $\geq 1$ years old } \\
\hline $\mathrm{BL}$ & 1,000 & & & & & & \\
\hline HG & $0,711^{* *}$ & 1,000 & & & & & \\
\hline WH & $0,616^{* *}$ & $0,744^{* *}$ & 1,000 & & & & \\
\hline RH & $0,551^{* *}$ & $0,780^{* *}$ & $0,876^{* *}$ & 1,000 & & & \\
\hline FL & $0,433^{* *}$ & $0,614^{* *}$ & $0,642^{* *}$ & $0,718^{* *}$ & 1,000 & & \\
\hline FW & $0,376^{* *}$ & $0,539^{* *}$ & $0,446^{* *}$ & $0,344^{* *}$ & $0,525^{* *}$ & 1,000 & \\
\hline BW & $0,882^{* *}$ & $0,948^{* *}$ & $0,707^{* *}$ & $0,697^{* *}$ & $0,547^{* *}$ & $0,505^{* *}$ & 1,000 \\
\hline
\end{tabular}

Note : ${ }^{* *}$ indicates that correlation is significant at the 0.01 level (2-tailed)

${ }^{*}$ indicates that correlation is significant at the 0.05 level (2-tailed).

Regression Analysis of Jabres Cattle Body Size: The regression analysis was performed for each group using multiple linear regression and factorial analysis scores followed by multiple linear regression methods. The multiple linear regression result can be seen in Table 4 . The best regression equation of each group was chosen 
by the highest R2, lowest standard error of estimate, lowest RMSE, lowest standard deviation ratio, and the normality of the residual. Each group had different predictors and thus different equation obtained. All of the equation had normal residual distribution. The best fit equation was obtained for male cattle with age same or above 1 years old. Contrarily, the worst fit equation was obtained for female cattle with age same or above 1 years old. It can be happened because the growth of adult cattle after 2 years old is non-linear so the body weight prediction became harder (Gano et al. 2015). The male cattle with age above 1 years only contained a few cattle with age above 2 years old, meanwhile the female cattle with age above laspects old contained many cattle with age above 2 years old. So it can be concluded that body weight if male Jabres cattle can be predicted more easily than female Jabres cattle with multiple linear regression method.

Compared to body weight prediction of adult Aceh cattle which use withers height, body length, and heart girth as predictors using multiple linear regression (Putra et al. 2014b), body weight prediction which obtained in this study gave higher determination coefficient for adult male Jabres cattle but lower determination coefficient for adult female Jabres cattle. Compared to adult female Ongole grade cattle, the body weight prediction equation from this study was less accurate which indicated by the smaller determination coefficient value (Paputungan et al. 2013).

Table 4. Linear regression model summary for body size of Jabres cattle with body weight as dependent variable.

\begin{tabular}{ccccc}
\hline \multirow{2}{*}{ Group } & \multicolumn{2}{c}{ Female } & \multicolumn{2}{c}{ Male } \\
\cline { 2 - 5 } & $<\mathbf{1}$ year old & $\geq \mathbf{1}$ year old & $<\mathbf{1}$ year old & $\geq \mathbf{1}$ year old \\
\hline Constant & -167.510 & -263.129 & -146.489 & -326.336 \\
Variable & & & & \\
BL & 1.405 & - & 0.873 & 2.178 \\
HG & 1.760 & 3.149 & 2.324 & 2,943 \\
WH & 0.088 & -0.077 & - & - \\
RH & -0.435 & 0.115 & -0.603 & -0.955 \\
FL & -0.187 & - & -0.292 & - \\
FW & - & - & -1.143 & -0.307 \\
Adjusted R & 0,968 & 0,726 & 0,971 & 0,990 \\
Std. Error of Estimate & 8,500 & 18.649 & 6,664 & 6,330 \\
RMSE & 8.171 & 18.533 & 6.193 & 6.118 \\
Standard Deviation & 0.174 & 0.521 & 0.161 & 0.099 \\
Ratio & & & & \\
\hline
\end{tabular}

Different from direct multiple linear regression which discussed previously, factorial analysis scores followed by multiple linear regression method did not use body size parameter directly to predict the body weight, but this method convert the body size parameter into several factors that will be used for body weight prediction. In the factorial analysis, the factor was extracted by principle components with factor number based on Eigenvalue greater than 1 as followed by Kaiser Rule criterion (Shah et al. 2018). The anti-image correlation, Kaiser-Meyer-Olkin Measure of Sampling Adequacy coefficient, and Barlett's Test of Sphericity significance evaluated in order to make sure the data appropriateness for factorial analysis. The anti-image correlation coefficient was above 0.50 for all variables, except for face width in female cattle with age same or above 1 years old which will be excluded in the factorial analysis. For the Kaiser-Meyer-Olkin Measure of Sampling Adequacy coefficient, the value are greater than 0.50 for all datasets. These low anti-image correlation coefficient value which supported by high Kaiser-Meyer-Olkin Measure of Sampling Adequacy coefficient indicate that partial correlations were low, true factors existed in the data, and the proportion of the variance in various body size parameter were exposed (Shah et al. 2018). Barlett's Test of Sphericity showed signifant result for all groups. After the requirements fulfilled, the factorial analysis was performed for each groups.

The result of factorial analysis was shown in Table 5. There was only 1 factor that can be extracted from each group data because only 1 component that had eigenvalue greater than 1. Almost all of the communalities of the variables had greater value than 0.50 which indicates that variables could describe factor. The extracted factor can explained the variance over than $50 \%$ which means that the factor can be used fo further analysis. The communality ranged from 0.217 (face length in female $\geq 1$ years old) to 0.969 (hearth girth in Male $<1$ years old). Higher estimates of communality (ranged from 0.79 to 0.93 ) were observed by Yakubu (2010) and approximate estimates of communality ( 0.42 to 0.87 and 0.32 to 0.83 ) were reported by Sadek et al. (2006). In the present study, common variance explains approximately. 
Table 5. Factorial analysis scores result of Jabres cattle body size.

\begin{tabular}{|c|c|c|c|c|c|c|c|c|}
\hline \multirow{3}{*}{ Variables } & \multicolumn{4}{|c|}{ Female } & \multicolumn{4}{|c|}{ Male } \\
\hline & \multicolumn{2}{|c|}{$<1$ years old } & \multicolumn{2}{|c|}{$\geq 1$ years old } & \multicolumn{2}{|c|}{$<1$ years old } & \multicolumn{2}{|c|}{$\geq 1$ years old } \\
\hline & Factor 1 & Communalities & Factor 1 & Communalities & Factor 1 & Communalities & Factor 1 & Communalities \\
\hline $\mathrm{BL}$ & 0.814 & 0.663 & 0.299 & 0.090 & 0.791 & 0.626 & 0.565 & 0.751 \\
\hline HG & 0.944 & 0.890 & 0.837 & 0.701 & 0.969 & 0.940 & 0.816 & 0.903 \\
\hline WH & 0.934 & 0.872 & 0.881 & 0.777 & 0.931 & 0.867 & 0.806 & 0.898 \\
\hline $\mathrm{RH}$ & 0.926 & 0.858 & 0.872 & 0.761 & 0.949 & 0.901 & 0.797 & 0.893 \\
\hline $\mathrm{FL}$ & 0.911 & 0.829 & 0.466 & 0.217 & 0.823 & 0.677 & 0.645 & 0.803 \\
\hline FW & 0.782 & 0.611 & 0 & 0 & 0.778 & 0.605 & 0.394 & 0.628 \\
\hline Eigenvalue & \multicolumn{2}{|r|}{4.724} & \multicolumn{2}{|r|}{2.545} & \multicolumn{2}{|r|}{4.615} & \multicolumn{2}{|r|}{4.023} \\
\hline $\begin{array}{c}\% \text { of } \\
\text { Variance }\end{array}$ & \multicolumn{2}{|r|}{78.728} & \multicolumn{2}{|r|}{50.901} & \multicolumn{2}{|r|}{76.917} & \multicolumn{2}{|r|}{67.043} \\
\hline
\end{tabular}

The factorial analysis scores were then used to predict body by multiple linear regression. The regression result was shown in Table 6 . The regression equation gave good fitness for cattle under 1 years old which indicated by high adjusted $\mathrm{R}^{2}$ value, low standard error of estimates and RMSE, and the standard deviation ratio were less than 0.40 . On the other hand, the regression equation which obtained for cattle same or above 1 years old gave bad fitness because the adjusted $\mathrm{R}^{2}$ value were low, standard error of estimates and RMSE were high, and the standard deviation ratio were more than 0.40 . It could be happen because the growth of adult cattle was more difficult to predict than young cattle.

Table 6. Linear regression equation of Jabres cattle body weight prediction calculated by factorial analysis scores followed by multiple linear regression.

\begin{tabular}{ccccc}
\hline \multirow{2}{*}{ Group } & \multicolumn{2}{c}{ Female } & Male \\
\cline { 2 - 5 } & $<$ 1 year old & $\geq \mathbf{1}$ year old & $<$ 1 year old & $\geq$ 1 year old \\
\hline Constant & 113.709 & 205.925 & 93.773 & 199.737 \\
Coefficient of Factor 1 & 44.216 & 27.223 & 36.865 & 54.772 \\
Adjusted R ${ }^{2}$ & 0.875 & 0.582 & 0.896 & 0.768 \\
Std. Error of Estimate & 16.727 & 23.041 & 12.520 & 30.036 \\
RMSE & 8.171 & 22.969 & 12.231 & 32.047 \\
Standard Deviation Ratio & 0.174 & 0.645 & 0.318 & 0.478 \\
\hline
\end{tabular}

The comparison of multiple regression or factorial analysis scores followed by multiple linear regression methods has been performed. In all cattle groups in this study, equations which were obtained from multiple linear regression method gave better fitness. It was indicated by the higher adjusted $\mathrm{R}^{2}$ value, lower standard error of estimates, lower RMSE, and lower standard deviation ratio. The graph between observed body weight and predicted body weight (Fig. 2) also showed that multiple linear regression method could predict the cattle body weight more accurately than factorial analysis scores followed by multiple linear regression method. It can be concluded that multiple linear regression method was preferable to be used to predict body weight of Jabres cattle than factorial analysis scores followed by multiple linear regression. The similar finding reported by Putra et al. (2014b) in Aceh cattle. Moreover, the equation which obtained by multiple linear regression method was more applicable for Jabres cattle farmers because they can use the cattle body size measurement result directly without need to transform it first to another form (i.e. factor) that should be done if they use factorial analysis scores followed by multiple linear regression method. 


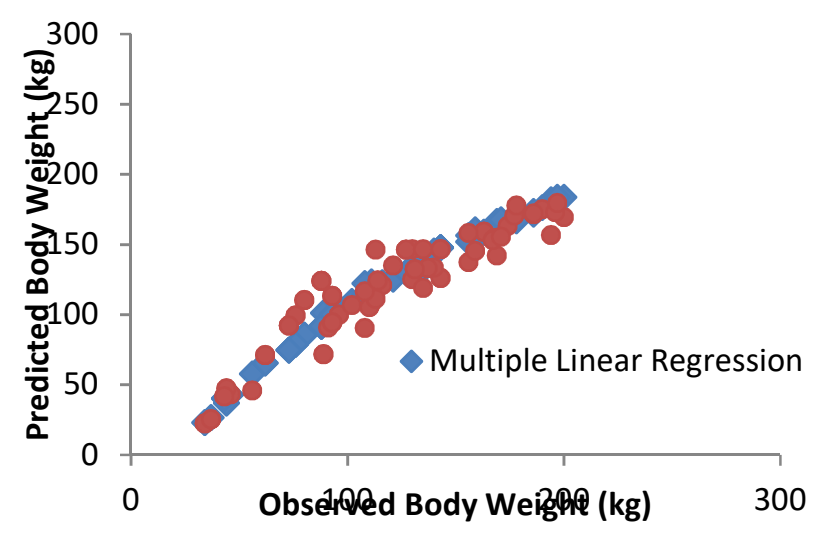

(a)

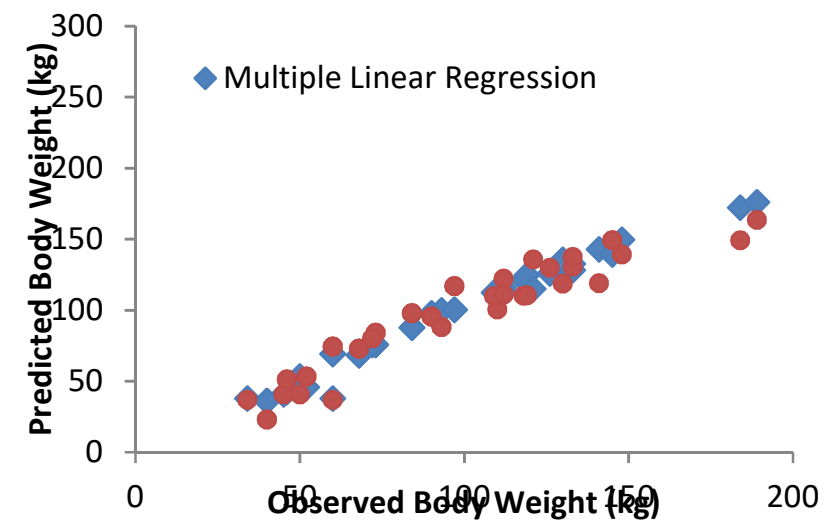

(c)

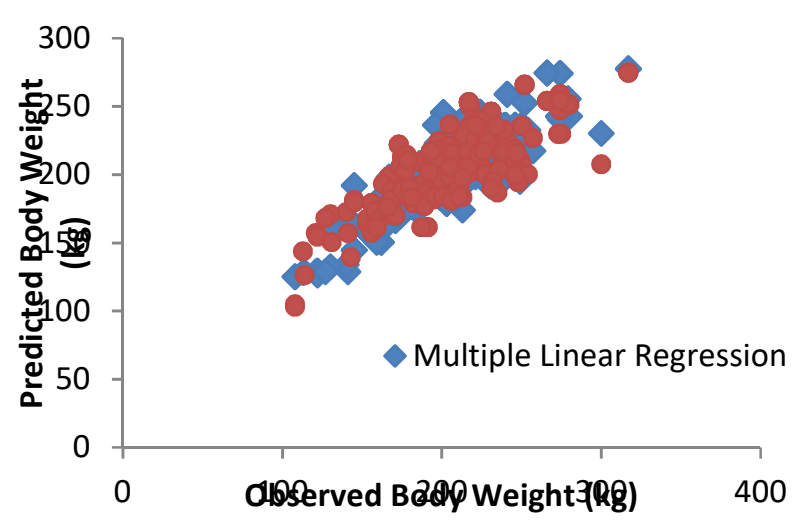

(b)

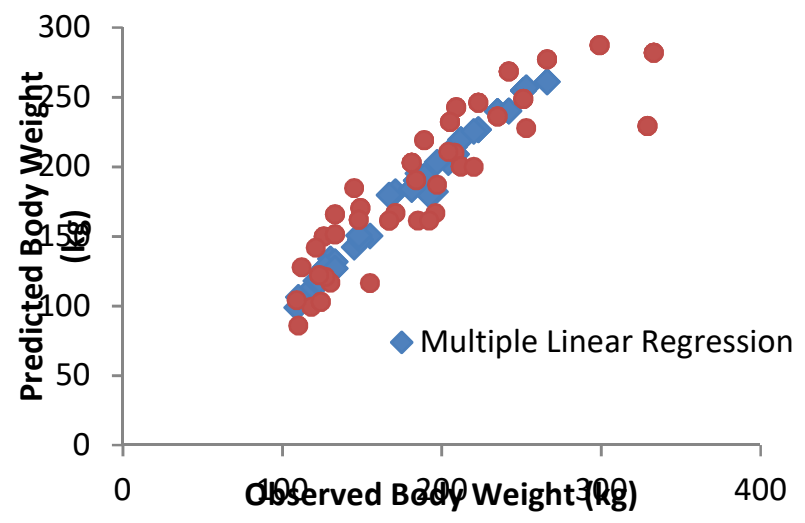

(d)

Fig. 2. Graph between observed body weight and predicted body weight which calculated by multiple linear regression $(\bullet)$ and factorial analysis scores followed by multiple linear regression $(\bullet)$ for female under 1 years old (a), female same or above 1 years old (b), male under 1 years old (c), and male same or above 1 years old (d) of Jabres cattle.

Conclusions: The Jabres cattle body size and body weight had been measured for 521 cattle which classified by sex and age. Age really matters to most of the body size parameter of Jabres cattle because the younger cattle have significant smaller body size than elder cattle. Generally, male Jabres cattle under 1 years old have significant smaller body size than female Jabres cattle under 1 years old, except for face length and face width which are not significantly different. However, for cattle same or above 1 years old, there are no significant difference between male and female cattle although female cattle have bigger body length, heart girth, face length, and body weight than male cattle. Correlation analysis showed that Jabres cattle have strong correlation among body size parameter in every group except female Jabres cattle same or above 1 years old. The highest corelation coefficient came from body weight and heart girth. The equation to predict body weight was obtained by multiple linear regression and factorial analysis scores followed by multiple linear regression methods. The result showed that multiple linear regression method was preferable to be used to predict body weight of Jabres cattle than factorial analysis scores followed by multiple linear regression because of its better accuracy, better fitness, and more applicable for Jabres cattle farmers.

Acknowledgements: The authors expressed special thanks to Ministry of Research and Higher Education of Indonesian Republic which has partly supported this research activities through Universitas Gadjah Mada, Yogyakarta, by providing scholarship of Master Education Program Leading to Doctoral Degree for Excellent Graduates (PMDSU) to the first author with contract number of 2046/UN1/DITLIT/DIT$\mathrm{LIT} / \mathrm{LT} / 2018$.

\section{REFERENCES}

Abdullah, M.A.N., R.R. Noor, H. Martojo, D.D. Solihin, and E. Handiwirawan (2007). The phenotypic variability of Aceh cattle in Nanggroe Aceh Darussalam. J. Indonesian. Trop. Anim. Agric.32(1): 11-21.

Adeyinka, I.A., and I.D. Mohammed (2006). Relationship of liveweight and linear body 
measurement in two breeds of goat of Northern Nigeria. J. Anim. Vet. Adv. 5(11): 891-893.

Adinata, Y., Aryogi, D. Pamungkas, M. Luthfi, A. Rasyid, and N.H. Krishna (2016). Phenotypic characterization of Jawa Brebes (Jabres) cattle. Proc. Int. Livest. Prod. Vet. Tech., 2:24.

Adiwinarti, R., I.P. Kusuma, and C.M.S. Lestari (2010). Performance of Ongole crossbred and Friesian Holstein crossbred young bulls feed consentrate and napier grass. Sains Peternakan. 8(1): 1-7.

FAO (2011). Draft guidelines on phenotypic characterization of animal genetic resources. Pub. L. No. CGRFA-13/11/Inf.19. Rome.

Gano, G., M. Blanco, I. Casasus, X. Cortes-Lacruz and D. Villalba (2015). Comparison of B-splines and non-linear functions to describe growth patterns and predict mature weight of female beef cattle. Anim. Prod. Sci. 56(11): 1787-1796.

Lestari, C.M.S., E. Purbowati, S. Dartosukarno, and E. Rianto (2014). Beef production and productivity systems Jawa-Brebes cattle raised traditionally. Jurnal Peternakan Indonesia. 16(1): 8-14.

Ministry of Agriculture of Indonesian Republic (2012). Decree of Ministy of Agriculture about Determination of Jabres Cattle Breed, Pub. L. No. 2842/Kpts/Lb.430/8/2012. Indonesia.

Mutua, F.K., C.E. Dewey, S.M. Arimi, E. Schelling, and W.O. Ogara (2011). Prediction of live body weight using length and girth measurements for pigs in rural Western Kenya. J. Swine. Health. Prod. 19(1): 26-33.

Ni'am, H.U.M., A. Purnomoadi, and S. Dartosukarno (2012). The relationship of body size and body weight of Bali cows in the various age groups. Anim. Agric. J.1(1): 541-556.

Ozkaya, S., and Y. Bozkurt (2008). The relationship of parameters of body measures and body weight by using digital image analysis in pre-slaughter cattle. Arch. Anim. Breed. 51(2): 120-128.

Panjono, P., M.S. Haq, C. Hanim, S. Andarwati, D. Maharani, D.T. Widayati, and I.G.S. Budisatria (2017). Proc. Int. Conf. Trop. Agric., 1:421.

Paputungan, U., L. Hakim, G. Ciptadi, and H.F.N. Lapian (2013). The estimation accuracy of live weight from metric body measurements in Ongole grade cows. J. Indonesian. Trop. Anim. Agric. 38(3): 149-155.

Prabowo, S., Rusman, and Panjono (2012). Carcass weight predictor variables of live Simmental crossbreed Ongole bulls. Bull. Anim. Sci. 36(2): 95-102.
Pundir, R.K., P.K. Singh, K.P. Singh, and P.S. Dangi (2011). Factor analysis of biometric traits of Kankrej cows to explain body conformation. Asian. Austral. J. Anim. 24(4): 449-456.

Putra, W. P. B, S. Sumadi, and T. Hartatik (2014a). The genetic correlation of growth traits in Aceh cattle at Indrapuri district Aceh Province. J. Agripet. 14(1): 37-41.

Putra, W.P.B., S. Sumadi, and T. Hartatik (2014b). The estimation of body weight of Aceh cattle using some measurements of body dimension. Jurnal Ilmu dan Teknologi Pertanian. 3(2): 76-80.

Sadek, M.H., A.Z. Al-Aboud, and A.A. Ashmawy (2006). Factor analysis of body measurements in Arabian horses. J. Anim. Breed. Genet. 123(6): 369-377.

Said, S., W.P.B. Putra, S. Anwar, P.P. Agung, and H. Yuhani (2017). Phenotypic, morphometric characterization and population structure of Pasundan cattle at West Java, Indonesia. Biodiversitas. 18(4): 1638-1645.

Shah, W.A., N. Ahmad, M. Saadullah, M. E. Babar, T. N. Pasha, S. Ahmad, A. Ali, Nasrullad, M. Z. Farooq, and A.H. Saleem (2018). Multivariate analysis of biometeric traits in Cholistani cattle. The J. Anim. Plant. Sci. 28(3): 940-944.

Suliani, S., A. Pramono, J. Riyanto, and S. Prastowo (2017). The relationship between body size and body weight of male Simmental Ongole crossbreed at various age in Jagalan Surakarta Abattoir. Sains Peternakan. 15(1): 16-21.

Sutarno, S., and A.D. Setyawan (2016). Review: The diversity of local cattle in Indonesia and the efforts to develop superior indigenous cattle breeds. Biodiversitas. 17(1): 275-295.

Thiruvenkadan, A.K. (2005). Determination of best-fitted regression model for estimation of body weight in Kanni Adu kids under farmer's management system. Livest. Res. 17(7): 1-11.

Tolenkhomba, T.C., D.S. Konsam, N.S. Singh, M. Prava, Y.D. Singh, M.A. Ali, and E. Motina (2012). Factor analysis of body measurements of local cows of Manipur, India. Int. Multidiscip. Res. J. 2(2): 77-82.

Ulutas, Z., M. Saatci, and A. Ozluturk (2001). Prediction of body weights from body measurements in East Anatolian Red calves. Atalürk Üniv. Ziraal Fak. Derg. 32(1): 61-65.

Yakubu, A. (2010). Path coefficient and path analysis of body weight and biometric traits in Yankasa lambs. Slovak. J. Anim. Sci. 43(1): 17-25. 